\title{
PROTECTIVE EFFECT OF DIOSGENIN AGAINST CARBON TETRACHLORIDE AND CISPLATIN INDUCED HEPATOTOXICITY IN RATS
}

\author{
Vikram V Nimbalkar ${ }^{1}$, Ravina P Shelke ${ }^{1}$, Urmila E Kadu ${ }^{1}$, Dr. Pandurang M Gaikwad $^{1}$ \\ ${ }^{1}$ Department of Pharmacology, \\ Dr. Vithalrao Vikhe Patil Foundation's College of Pharmacy, Vilad Ghat, Ahmednagar (MS), India.
}

\section{ABSTRACT}

Background: Activation of hepatic stellate cells (HSC) plays central role in the development of liver fibrosis. In HSC activation, the transforming growth factor- $\beta 1$ (TGF- $\beta 1$ ) is considered to be the main stimuli factor. Diosgenin are the steroidal saponin and found in Trigonella foenum graecum Linn (Fenugreek) and some other species of Dioscorea. Diosgenin attenuates HSC activation by inhibiting transforming growth factor- $\beta$. Aim: In present study an attempt was made to explore the effect of diosgenin on liver fibrosis. Methods: Liver fibrosis was induced in rats by carbon tetrachloride $\left(\mathrm{CCl}_{4}\right) 1 \mathrm{ml} / \mathrm{kg}$ intraperitoneally twice a week for 28 days and cisplatin $3 \mathrm{mg} / \mathrm{kg}$ intraperitoneally at 0,1 , 3 week for 4 weeks. The extent of liver fibrosis was assessed by measuring the weight of liver and levels of total bilirubin (TBL), hydroxyproline (HP) and serum enzymes due to deposition of extracellular matrix (ECM). Results: The administration of diosgenin reduced the liver weight of $\mathrm{CCl}_{4}$ and cisplatin treated animals and reduced the TBL, HP level and serum enzymes significantly and inhibited liver fibrosis induced by $\mathrm{CCl}_{4}$ and cisplatin. Conclusion: The result obtained in the present investigation, Diosgenin treatment exerted significant hepatoprotective effect in animals by inhibiting ECM deposition and HSCs activation.

KEYWORDS: Liver fibrosis; $\mathrm{CCl}_{4}$; Cisplatin; Diosgenin; Hepatoprotective; Antifibrotic effect.

\section{INTRODUCTION}

Liver fibrosis is one of the most widespread chronic liver diseases in the world. Fibrosis is the wound healing response of an organ and formation of fibrous scar tissue[1].During liver fibrosis there is an excessive production and deposition of extracellular matrix protein (ECM) including collagen which disrupts the normal structure of the liver and cause activation of hepatic stellate cells (HSCs) [2, 3].Nonalcoholic fatty liver diseases (NAFLD), alcoholic liver diseases, chronic hepatitis B (HBV) and hepatitis $C$ (HCV) are the most common causes of liver fibrosis[4, 5].

Fibrosis is the first stage of liver cells scarring and later if more of the liver becomes scarred, it's known as liver cirrhosis. A scar is a fibrous tissue made up of collagen that replaces the injured cells, performs no function, type I and type III are the types of collagen that makeup scar tissue. Typically, a hepatic stellate cells (HSCs) play acentral role in the pathogenesis of hepatic

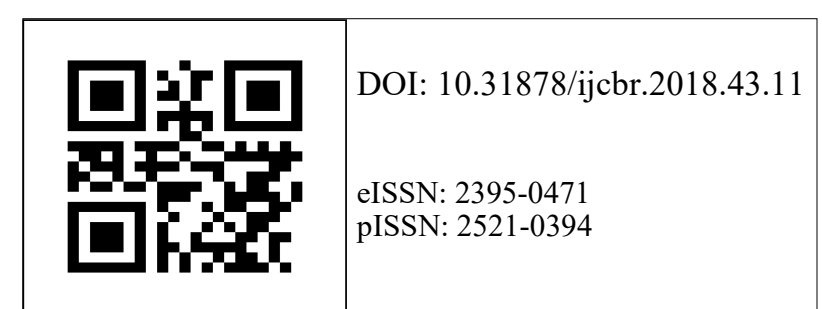

fibrosis and comprise $15 \%$ of the liver cell mass[6]. The activation of Cellular component primarily hepatic stellate cells is important during the initiation and development of liver fibrosis[2]. Hepatic stellate cell stores vitamin A as retinyl esters, due to the liver fibrosis HSCs proliferate, lose their vitamin $A$ and undergo major phenotypical transformation to myofibroblast (activated HSCs) that increasingly express $\alpha$-smooth muscle actin and produces collagenous extracellular matrix proteins[7].The transforming growth factor- $\beta 1$ (TGF- $\beta 1$ ) is a cytokine, important in hepatic stellate cells activation and proliferation and regulation of ECM formation[8].TGF- $\beta 1$ is acted in an autocrine and paracrine manner and is produced by kupffer cells[9].

Matrix metalloproteinase (MMP) have capability to degrade the ECM component. But in fibrotic liver there is an expression of tissue inhibitor of metalloproteinases, which inhibit the MMP and play a key role in fibrogenesis. Therefore, the inactivation of activated HSC is a key process for the recovery from liver fibrosis[1]. Fibrosis can occasionally reverse if the cause is identified rapidly. Fibrosis can develop because of continuously damaging cells for month or year. Diosgenin has shown antioxidant, hypolipidaemic activity. This research demonstrated that activity of herbal medicine diosgenin that has acts against liver fibrosis through inhibition of cytokine production[10].

Correspondence: Ravina P Shelke, Department of Pharmacology, Dr. Vithalrao Vikhe Patil Foundation's College of Pharmacy, Vilad Ghat, Ahmednagar (MS), India. Email: rajevikram@gmail.com 
Ravine et al. Protective effect of Diosgenin against Carbon tetrachloride and Cisplatin induced hepatotoxicity in rats.

\section{MATERIALS AND METHODS}

Study design: An experimental animal based study

Ethics approval: The experimental protocol was approved by the institutional animal ethics committee. (COPH/IAEC/PG/05/2018).

Study location: Dr. V.V.P.F's College of Pharmacy, Ahmednagar.

\section{Study duration: 28 days}

Animals: The healthy Albino Wistar rats of either sex, weighing between 180-250 g were taken for the study. They were housed under standard environmental conditions of temperature $(23 \pm 20$ c) humidity $(55 \pm 5 \%)$ and $12 \mathrm{~h}$ light and $12 \mathrm{~h}$ dark cycles. The animals were fed with standard pellet diet and water ad labium. The experimental protocol was approved by the institutional animal ethical committee as per the CPCSEA guidelines.

Sample size: In each group $n=6$

Drug and chemicals: Cisplatin was purchased from Hetero Healthcare Ltd, Diosgenin was purchased from Yarrow Chem Products, Carbon tetrachloride was purchased from Qualigens Fine chemicals and other reagent were purchased from local market, all this chemicals used in this studies were analytical grade.

Dose Selection of Drug: Studies assessing Diosgenin for toxicity study have shown that the compound was usually well tolerated orally in doses of up to $500 \mathrm{mg} / \mathrm{kg}$. The selected doses of Diosgenin 50,100, $150 \mathrm{mg} / \mathrm{kg}$ body weight for the rats. They were given by oral route using oral gavage [11].

Experimental protocol: Test compound formulation: Diosgenin was suspended in $0.5 \% \mathrm{w} / \mathrm{v}$ gum tragacanth in distilled water[1] .

Induction of liver fibrosis by Carbon tetrachloride: The rats were subjected to intraperitoneally administration of $1 \mathrm{ml} / \mathrm{kg} \mathrm{CCl} 4$ mixed with an equal volume of olive oil, twice a week for 28 days.

\section{Methodology}

\section{Experimental design: $1 . \mathrm{CCl} 4$ Induced liver fibrosis:}

The animals were divided into 5 groups of six animals in each group.

Group I (control) -received distilled water ( $1 \mathrm{ml} / \mathrm{kg}$, p.o.) for 28 days

Group II (Negative control) -received CCl4 (1 ml/kg i.p.) twice a week for 28 days

Group III -received CCl4 (1 ml/kg i.p.) twice a week for 28 days and Diosgenin ( $50 \mathrm{mg} / \mathrm{kg}$ p.o. daily) for 28 days

Group IV-received CCl4 (1 ml/kg i.p.) twice a week for 28 days and Diosgenin (100 mg/kg p.o. daily) for 28 days

Group V- received CCl4 (1 ml/kg i.p.) twice a week for 28 days and Diosgenin (150 mg/kg p.o. daily) for 28 days $[1,12]$

\section{Cisplatin induced liver fibrosis:}

The animals were divided into 5 groups of six animals in each group.

Group I (control)-received distilled water $(1 \mathrm{ml} / \mathrm{kg}$, p.o.) for 28 days

Group II (Negative control)-received cisplatin $(3 \mathrm{mg} / \mathrm{kg}$ i.p.) at $0,1,3$ week for 4 weeks Group III-received cisplatin (3mg/kg i.p.) at 0,1, 3 week for 4 weeks or 28 daysand Diosgenin ( $50 \mathrm{mg} / \mathrm{kg}$ p.o, daily) for 28 days

Group IV- received cisplatin (3mg/kg i.p.) 0, 1, 3 week for 4 weeks or 28 daysand Diosgenin (100 mg/kg p.o, daily) for 28 days

Group V- received cisplatin (3mg/kg i.p.) 0, 1, 3 week for 4 weeks or 28 daysand Diosgenin (150 mg/kg p.o, daily) for 28 days[13, 14].

Estimation of different parameters: After 28 days of both $\mathrm{CCl} 4$ and cisplatin induced liver fibrosis methods, the animals were kept to fasting overnight after the experimental period. They were anaesthetized with ether and blood was collected by puncturing retroorbital plexus and left at room temperature for 30 minutes in dry test tubes without any disturbance. Then the blood samples were centrifuged for 10 minutes at $3000 \mathrm{rpm}$ to separate the serum.

Biochemical parameter: At the end of treatment the serum was subjected to various biochemical tests to assess liver function such as aspartate transaminase (AST), alanine transaminase (ALT), alkaline phosphatase (ALP) and total bilirubin (TBL). The livers were homogenized to estimate the level of hydroxyproline (HP).

Morphological parameter: After completion of the experimental period the animals were sacrificed and abdomen was cut and open the liver was isolated and the weight of the liver was measured.

Histo-pathological studies: Livers were dissected out and preserved in $10 \%$ formalin for Histopathological studies. Liver sections were stained with haematoxylin and eosin, the stained sections were observed under the microscope to estimate the extent of liver fibrosis.

Statistical analysis: Results were expressed as the Mean \pm standard error means (S.E.M). The comparison of data within groups was performed by the analysis of variance using ANOVA test. Significant difference between control and experimental groups was assessed by Dunnetts test. Statistical analysis was performed using INTA. A probability level of less than $p<0.05$ was considered significant. 
Ravine et al. $\square$ Protective effect of Diosgenin against Carbon tetrachloride and Cisplatin induced hepatotoxicity in rats.

Table 1. Effect of diosgenin treatment on different biochemical parameters and liver weight in $\mathrm{CCl}_{4}$ induced liver fibrosis:

\begin{tabular}{|c|c|c|c|c|c|c|}
\hline \multirow[b]{2}{*}{$\begin{array}{l}\text { Sr. } \\
\text { No. }\end{array}$} & \multirow{2}{*}{$\begin{array}{l}\text { Biochemical } \\
\text { parameters }\end{array}$} & \multicolumn{5}{|l|}{ Group } \\
\hline & & Control & $\begin{array}{l}\text { Negative } \\
\text { control }\end{array}$ & $\mathrm{T}-50$ & $\mathrm{~T}-100$ & T-150 \\
\hline 1 & AST (U/ml) & $\begin{array}{l}43 \\
\pm 1.065\end{array}$ & $71.16^{\# \#} \pm 0.703$ & $\begin{array}{l}66.33 * * \\
\pm 0.881\end{array}$ & $\begin{array}{l}53.33 * * \\
\pm 1.453\end{array}$ & $\begin{array}{l}51.16 * * \\
\pm 0.872\end{array}$ \\
\hline 2 & ALT (U/ml) & $\begin{array}{l}35.5 \\
\pm 2.012 \\
\end{array}$ & $\begin{array}{l}104^{\# \#} \\
\pm 1.701 \\
\end{array}$ & $\begin{array}{l}65.33^{* *} \\
\pm 1.453 \\
\end{array}$ & $\begin{array}{l}45 * * \\
\pm 1.826 \\
\end{array}$ & $\begin{array}{l}40.16 * * \\
\pm 2.414\end{array}$ \\
\hline 3 & $\begin{array}{l}\text { ALP } \\
\text { (KA units/dl) }\end{array}$ & $\begin{array}{l}7.85 \\
\pm 0.260\end{array}$ & $\begin{array}{l}21.095^{\# \#} \\
\pm 0.388\end{array}$ & $\begin{array}{l}17.038^{* *} \\
\pm 0.429\end{array}$ & $\begin{array}{l}15.35 * * \\
\pm 0.277\end{array}$ & $\begin{array}{l}11.94 * * \\
\pm 0.323\end{array}$ \\
\hline 4 & TB (mg/dl) & $\begin{array}{l}0.45 \\
\pm 0.20 \\
\end{array}$ & $\begin{array}{l}1.52^{\# \#} \\
\pm 0.016\end{array}$ & $\begin{array}{l}0.57^{* *} \\
\pm 0.026\end{array}$ & $\begin{array}{l}0.77 * * \\
\pm 0.027\end{array}$ & $\begin{array}{l}0.65 * * \\
\pm 0.014\end{array}$ \\
\hline 5 & $\mathrm{HP}(\mu \mathrm{g} / \mathrm{g})$ & $\begin{array}{l}50.66 \\
\pm 2.515\end{array}$ & $\begin{array}{l}135^{\# \#} \\
\pm 3.270\end{array}$ & $\begin{array}{l}110 * * \\
\pm 2.887\end{array}$ & $\begin{array}{l}78.33^{* *} \\
\pm 2.108\end{array}$ & $\begin{array}{l}63.35 * * \\
\pm 1.667\end{array}$ \\
\hline 6 & Liver weight (gm) & $\begin{array}{l}4.5 \\
\pm 0.089\end{array}$ & $\begin{array}{l}7.56^{\# \#} \\
\pm 0.079\end{array}$ & $\begin{array}{l}6.31 * * \\
\pm 0.040\end{array}$ & $\begin{array}{l}6.18 * * \\
\pm 0.044\end{array}$ & $\begin{array}{l}5.15 * * \\
\pm 0.040\end{array}$ \\
\hline
\end{tabular}

$\mathrm{n}=6$, values are expressed as Mean \pm SEM. Comparison were made as follows, \# $p<0.05$, \#\# $p<0.01$ when compared with Normal control and ${ }^{*} p<0.05,{ }^{* *} p<0.01$ when compared with negative control. Data was statistically analyzed by one way ANOVA followed by Dunnetts test.

\section{RESULTS}

1. Effect on $\mathrm{CCl} 4$ induced liver fibrosis: At the end of 28 days treatment of diosgenin in $\mathrm{CCl} 4$ induced liver fibrosis, the animals were subjected for biochemical investigation. Serum level of AST, ALT, ALP, TB and HP were analyzed and shown in Table 1.

$\mathrm{T}-50$ = Diosgenin treated group $(50 \mathrm{mg} / \mathrm{kg})$

$\mathrm{T}-100=$ Diosgenin treated group $(100 \mathrm{mg} / \mathrm{kg})$

$\mathrm{T}-150$ = Diosgenin treated group $(150 \mathrm{mg} / \mathrm{kg})$

When the negative control group was compared with normal control group, there is significant (\#\#p<0.01) increase in the serum level of AST, ALT, ALP, TB and level of Hydroxyproline. There is significant $(* * p<0.01)$ decrease in the serum level of $A S T, A L T, A L P, T B$ and level of HP in T-50 ( $\mathrm{CCl} 4$ + Diosgenin $50 \mathrm{mg} / \mathrm{kg} \mathrm{p.o)}$, T100 (CCl4 + Diosgenin $100 \mathrm{mg} / \mathrm{kg}$ p.o.) and T-150 (CCl4 + Diosgenin $150 \mathrm{mg} / \mathrm{kg}$ p.o.) group when compared with negative control group.

Effect on liver weight in $\mathrm{CCl} 4$ induced liver fibrosis: When the liver weight of the negative control group was compared with control group, there is significant $(\# \# p<0.01)$ increase in the liver weight of negative control group due to ECM deposition or fatty infiltration. There is significant $(* * p<0.01)$ decrease in liver weight of T-50, T-100 and T-150 group when compared with negative control group.

\subsection{Histopathological examinations}

Histopathological examinations of the rat livers in CCl4 induced liver fibrosis:

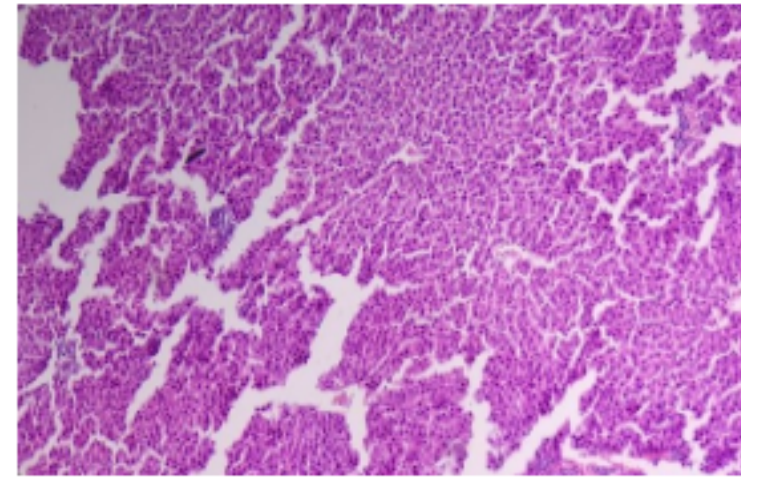

Figure 1: Group-I showed the structure of liver with normal hepatocytes surrounding the central vein and normal periportal area.

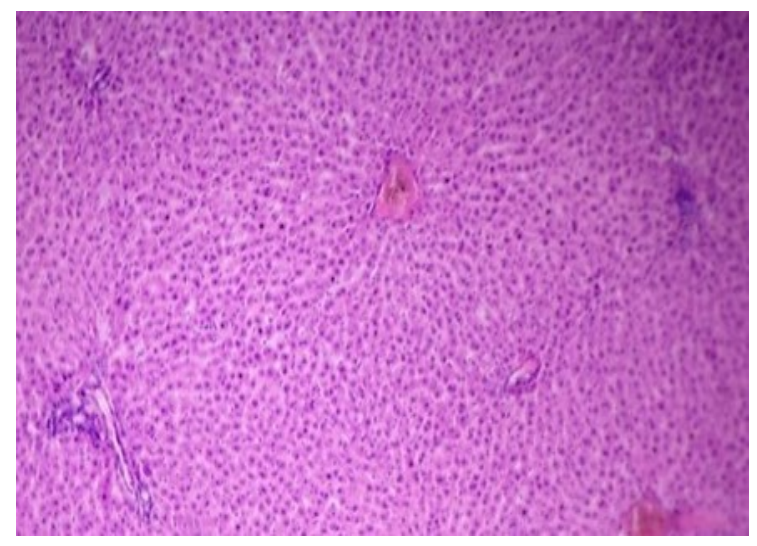

Figure 2: Group-Il showed liver parenchyma with sheets of hepatocytes showing fatty change, areas of severe necrosis and periportal area shows dense fibrosis. 


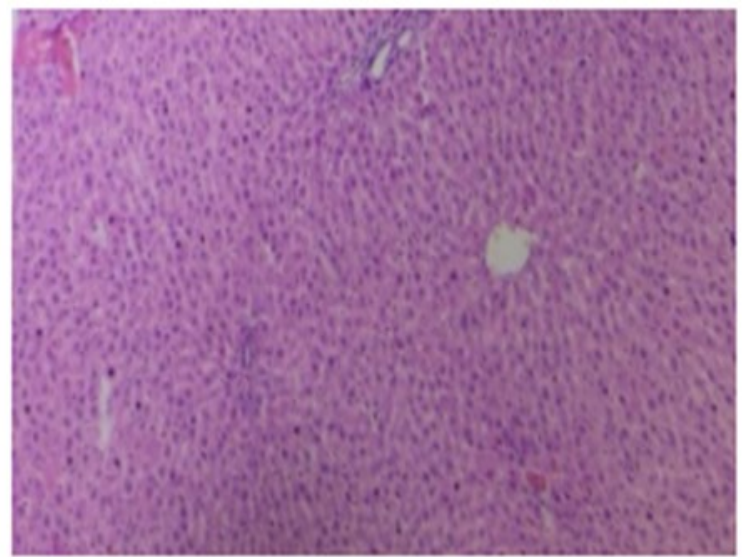

Figure 3: Group-III showed liver parenchyma with sheets of hepatocytes showing mild fatty infiltration.

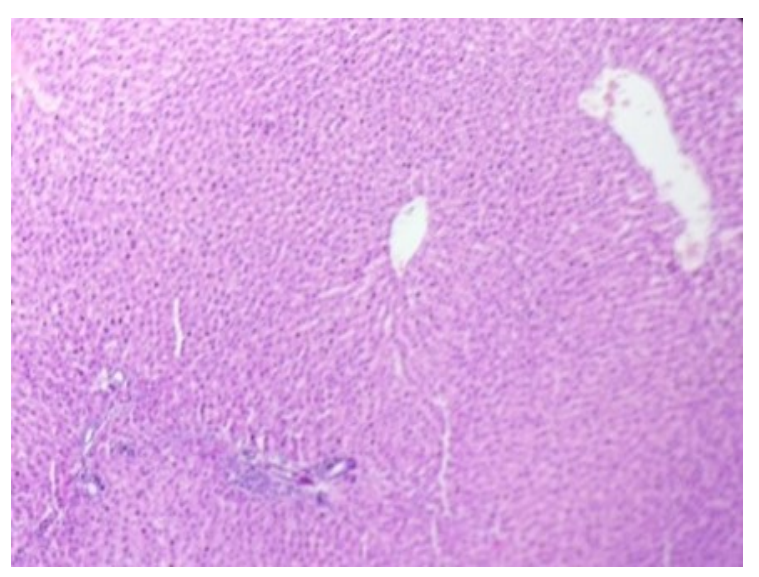

Figure 4: Group-IV showed liver parenchyma with sheets of hepatocytes showing mild necrosis.

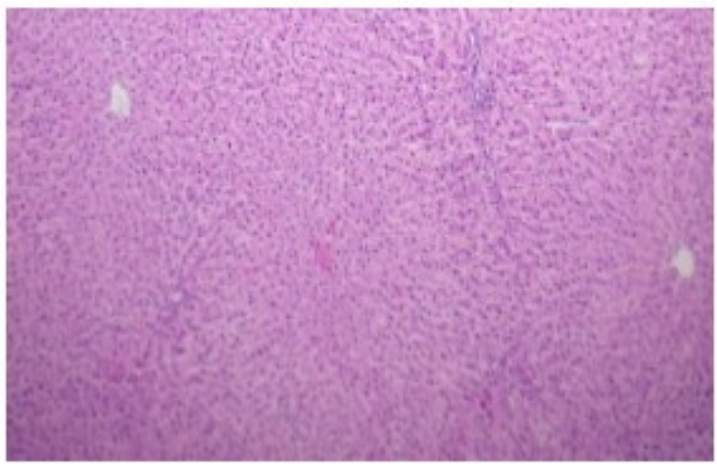

Figure 5: Group-V showed liver parenchyma with sheets of hepatocytes showing areas of, mild periportal fibrosis and sinusoids showed dilation.

\section{Effect on Cisplatin induced liver fibrosis:}

At the end of 28 days treatment of diosgenin in cisplatin induced liver fibrosis, serum level of AST, ALT, ALP, TB and HP were analyzed.

There is significant (\#\# $p<0.01$ ) increase in the serum level of AST, ALT, ALP, TB and level of hydroxyproline (HP) when the negative control group was compared with normal control group. There is significant $(* *$ $p<0.01)$ decrease in the serum level of AST, ALT, ALP TB and level of HP in T-50 (Cisplatin + Diosgenin $50 \mathrm{mg}$ / kg p.o.), T-100 (Cisplatin + Diosgenin 100 mg/kg p.o.) and T-150 (Cisplatin + Diosgenin $150 \mathrm{mg} / \mathrm{kg}$ p.o.) group when compared with negative control group.

Effect on liver weight in Cisplatin induced liver fibrosis:

There is significant $(\# \# p<0.01)$ increase in the liver weight of negative control group (Cisplatin) When com-

Table 2. Effect of diosgenin treatment on different biochemical parameters and liver weight in Cisplatin induced liver fibrosis

\begin{tabular}{|c|c|c|c|c|c|c|}
\hline \multirow[b]{2}{*}{$\begin{array}{l}\text { Sr. } \\
\text { No. }\end{array}$} & \multirow{2}{*}{$\begin{array}{l}\text { Biochemical } \\
\text { parameters }\end{array}$} & \multicolumn{5}{|l|}{ Group } \\
\hline & & Control & $\begin{array}{l}\text { Negative } \\
\text { control }\end{array}$ & T-50 & T-100 & T-150 \\
\hline 1 & $\begin{array}{l}\text { AST } \\
(\mathrm{U} / \mathrm{ml}) \\
\end{array}$ & $44 \pm 1.32$ & $\begin{array}{l}71.5^{\# \#} \\
\pm 0.763 \\
\end{array}$ & $\begin{array}{c}69.33 * * \\
\pm 1.282 \\
\end{array}$ & $\begin{array}{l}52.33 * * \\
\pm 1.453 \\
\end{array}$ & $\begin{array}{l}51.16 * * \\
\pm 0.872 \\
\end{array}$ \\
\hline 2 & $\begin{array}{l}\text { ALT } \\
(\mathrm{U} / \mathrm{ml})\end{array}$ & $\begin{array}{l}37.33 \\
\pm 1.63 \\
\end{array}$ & $\begin{array}{l}103.16^{\# \#} \\
\pm 1.249\end{array}$ & $\begin{array}{l}62.33 * * \\
\pm 1.308 \\
\end{array}$ & $\begin{array}{l}46.66 * * \\
\pm 1.619 \\
\end{array}$ & $\begin{array}{l}40.16 * * \\
\pm 1.301 \\
\end{array}$ \\
\hline 3 & $\begin{array}{l}\text { ALP } \\
\text { (KA units/dl) }\end{array}$ & $\begin{array}{l}8.94 \\
\pm 0.338 \\
\end{array}$ & $\begin{array}{l}32.43^{\# \#} \\
\pm 0.694\end{array}$ & $\begin{array}{l}24.77 * * \\
\pm 0.548\end{array}$ & $\begin{array}{l}19.422 * * \\
\pm 0.306\end{array}$ & $\begin{array}{l}11.94 * * \\
\pm 0.323\end{array}$ \\
\hline 4 & $\begin{array}{l}\text { TB } \\
(\mathrm{mg} / \mathrm{dl})\end{array}$ & $\begin{array}{l}0.43 \\
\pm 0.017 \\
\end{array}$ & $\begin{array}{l}1.52^{\# \#} \\
\pm 0.014 \\
\end{array}$ & $\begin{array}{l}0.53 * * \\
\pm 0.095 \\
\end{array}$ & $\begin{array}{l}0.74 * * \\
\pm 0.016 \\
\end{array}$ & $\begin{array}{l}0.65 * * \\
\pm 0.010 \\
\end{array}$ \\
\hline 5 & $\begin{array}{l}\mathrm{HP} \\
(\mu \mathrm{g} / \mathrm{g}) \\
\end{array}$ & $\begin{array}{l}49.66 \\
\pm 2.404 \\
\end{array}$ & $\begin{array}{l}140^{\# \#} \\
\pm 2.887 \\
\end{array}$ & $\begin{array}{l}120 * * \\
\pm 2.884 \\
\end{array}$ & $\begin{array}{l}90 * * \\
\pm 2.887 \\
\end{array}$ & $\begin{array}{l}80 * * \\
\pm 2.887 \\
\end{array}$ \\
\hline 6 & Liver weight (gm) & $\begin{array}{l}4.53 \\
\pm 0.09\end{array}$ & $\begin{array}{l}7.39^{\# \#} \\
\pm 0.09\end{array}$ & $\begin{array}{l}6.43 * * \\
\pm 0.09\end{array}$ & $\begin{array}{l}6.30 * * \\
\pm 0.057\end{array}$ & $\begin{array}{l}5.35 * * \\
\pm 0.050\end{array}$ \\
\hline
\end{tabular}

$\mathrm{n}=6$, values are expressed as Mean \pm SEM. Comparison were made as follows, \# $p<0.05, \# \#$ p $<0.01$ when compared with Normal control and* $p<0.05, * * p<0.01$ when compared with negative control. Data was statistically analyzed by one way ANOVA followed by Dunnetts test 
Ravine et al. $\square$ Protective effect of Diosgenin against Carbon tetrachloride and Cisplatin induced hepatotoxicity in rats.

pared with control group. There is significant $(* *$ $p<0.01)$ decrease in liver weight of T-50, T-100 and T150 group when compared with negative control group.

\subsection{Histopathological examination}

Histopathological examination of the rat livers in cisplatin induced liver fibrosis:

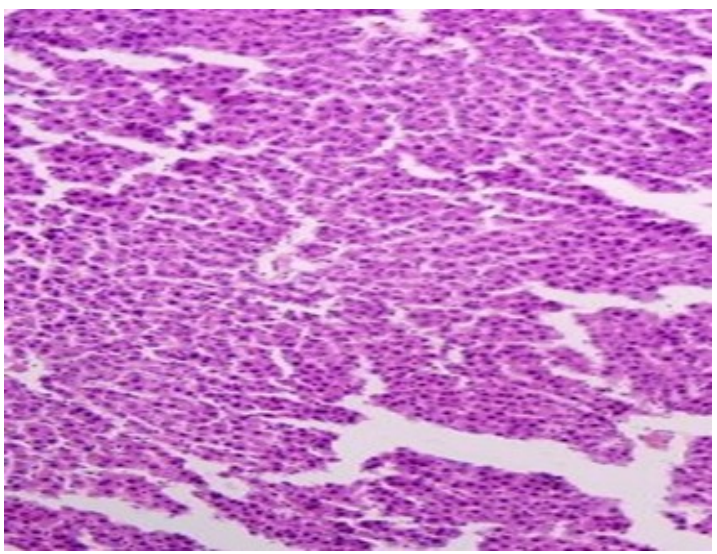

Figure 6: group-I showed the structure of liver with normal periportal area

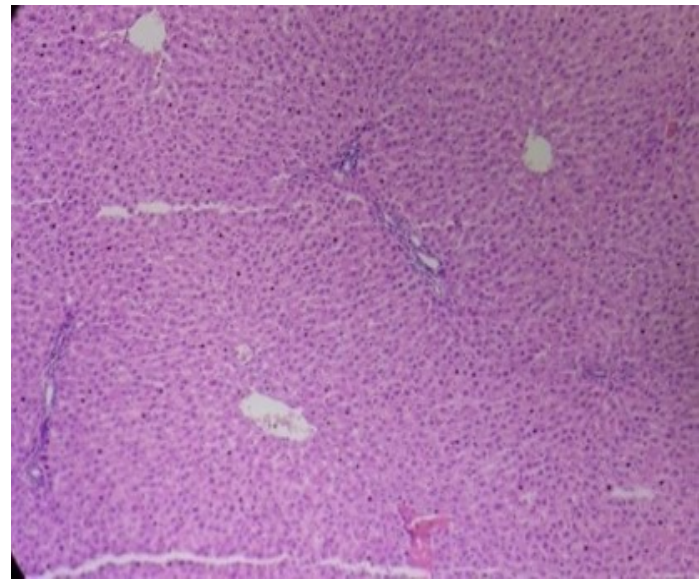

Figure 7: Group-II showed dense ECM infiltration, inflammation and periportal fibrosis

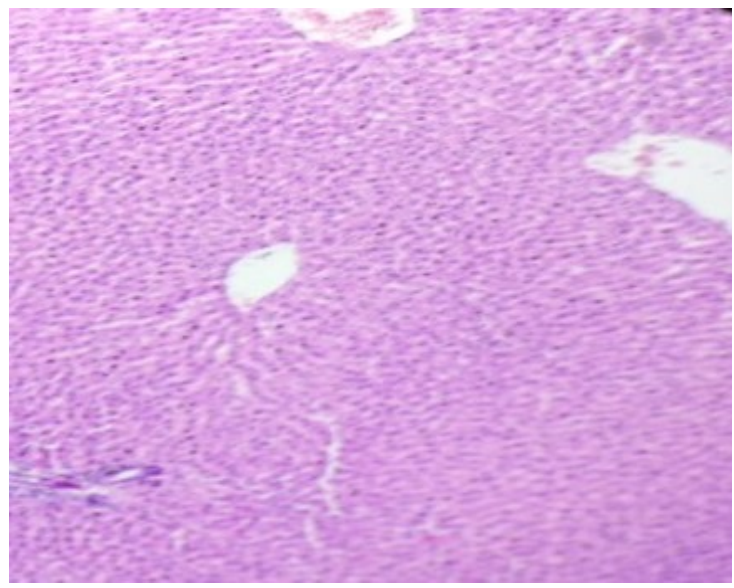

Figure 8: Group-III showed mild ECM infiltration.

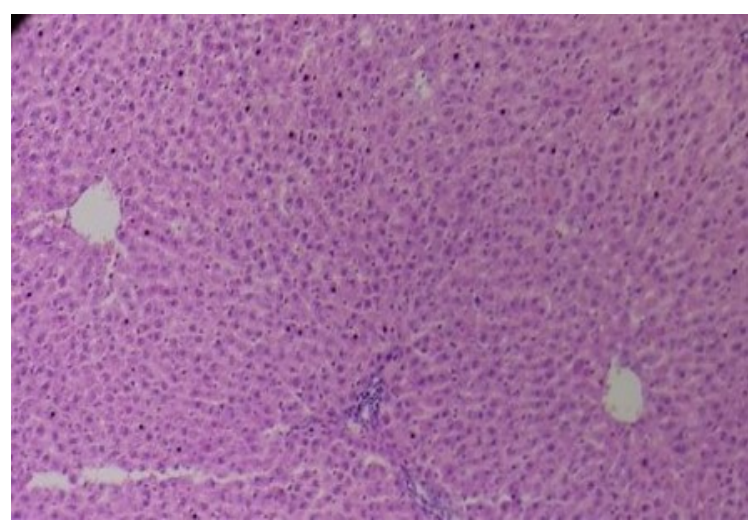

Figure 9: Group- IV The section from group-IV showed liver parenchyma with sheets of hepatocytes showing mild inflammation.

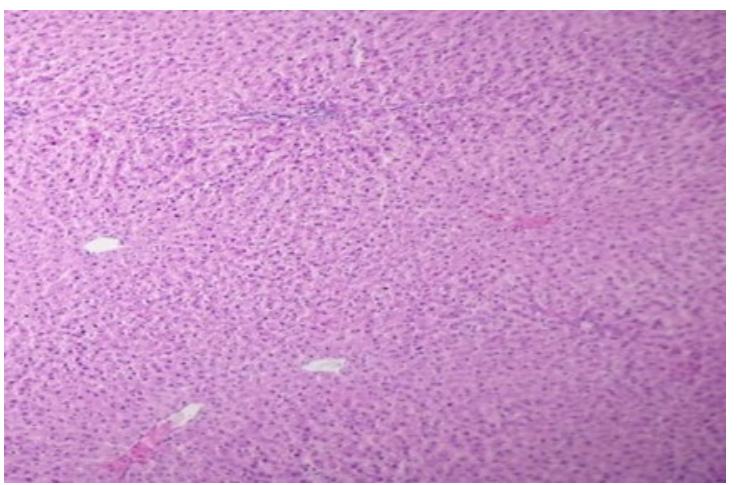

Figure 10: Group-V showed, tissue is free from inflammatory cells.

\section{DISCUSSION}

Many herbal drugs possess hepatoprotective effect hence can be used for the management of various liver diseases. The $\mathrm{CCl} 4$ possess hepatotoxic effect in the experimental animals. The enzyme cytochrome P450 biotransformed $\mathrm{CCl} 4$ and produce the trichloromethyl free radicals, which cause lipid peroxidation of lipids membrane and peroxidative degradation in the adipose tissue resulting in fatty or ECM infiltration of the hepatocytes. All these events culminate in loss of integrity of cell membrane and damage of hepatic cells [15]. Free radical generation causes oxidative damage due to hepatotoxic effect of $\mathrm{CCl} 4$.In hepatotoxicity, cause liver damage due to serum enzymes leak into blood stream. The elevated levels of biomarker (AST, ALT, ALP), TBL and $\mathrm{HP}$ are indications of hepatotoxicity in $\mathrm{CCl}$ 4induced rats.

In our study, a repeated administration of $\mathrm{CCl} 4$ for four weeks (twice a week) to the experimental animals led to progressive deterioration of liver structure, with a subsequent liver fibrosis [7]. In the present study, the transaminase (AST, ALT, ALP) level increased by $\mathrm{CCl} 4$ treatment was significantly $(p<0.01)$ reduced by diosgenin treatment T-50, T-100 and T150. The total bilirubin and HP level was also restored to the near normal level upon $\mathrm{CCl} 4$ intoxication by the diosgenin treat- 

rats.

ment. These findings were further supported by histopathological studies, which clearly indicated that the hepatic fibrosis occurred in negative control group and increased liver weight and HP content were also seen in negative control group. HP content is good marker of liver fibrosis. The increased weight of liver by $\mathrm{CCl} 4$ was restored by diosgenin (T-150) up to the near normal significantly $(p<0.01)$. This revels that diosgenin treatment prevented the ECM deposition in the liver cells and indicating hepatoprotective and antifibrotic action. The comparative Histopathological study of the liver from different groups of rat corroborated the hepatoprotective efficacy of the diosgenin. Various pathological changes like steatosis, fatty change, areas of severe necrosis, periportal inflammatory infiltrate and periportal fibrosis, associated with liver fibrosis were prevented to moderate extent in treatment group.

High doses of cisplatin have been known to produce hepatotoxicity [16]. Hepatotoxicity induced by cisplatin is recognized by the alteration of the biochemical, histological, and molecular parameters. As ALT exists mainly in the liver cell cytoplasm, it is one of the most sensitive parameters for liver cell function test as recommended by WHO. The result of our study showed that activities of serum enzymes (ALT, AST, and ALP) in negative control group increased in comparison with the control group. ALT, AST, and ALP enzymes levels increase in serum confirmed hepatocytes cell membrane damage and enzymes leak from the hepatocytes [12]. Our result showed that cisplatin makes dosedependent changes in liver structure: some of these changes impair hepatocytes arrangement, liver lobulation, and necrosis. This study also confirmed that addition of some antioxidant foods may have preventive effects on cisplatin induced hepatotoxicity. The difference in weight of animals after the experiment showed a significant difference between normal control and negative control group.

In the present study, administration of Cisplatin for 0 , 1,3 weeks to the experimental animals cause impairment of liver architecture, with a progression of liver fibrosis [7]. In the present study, the transaminase (AST, ALT, ALP) level increased by Cisplatin treatment was significantly $(p<0.01)$ decrease by diosgenin treatment groups. The increased weight of liver by Cisplatin was restored by diosgenin T-150 up to the near normal significantly $(p<0.01)$ after 28 days. Result in diosgenin treatment prevented cisplatin induced liver fibrosis. In the Histopathological study of the liver from different groups of rat normal control group shows normal hepatic cells and, where as administration of Cisplatin in negative control group showed portal fibrosis and treated group showed mild ECM infiltration.

\section{CONCLUSION}

In conclusion, there have been considerable advances in the understanding of the mechanisms that underlie hepatic fibrogenesis. The central event in fibrogenesis appears to be the activation of HSCs, which is a complex process. Taking into consideration the results obtained in the present investigation, it can be concluded that, Diosgenin treatment exerted significant hepatoprotective effect in laboratory animals by inhibiting ECM deposition and HSCs activation.

ACKNOWLEDGMENT: The authors are thankful to Dr. S. H. Khaparde, Department of Pathology, Dr.V.V.P.F's Medical College for Histopathological studies.

\section{REFERENCES}

1. Thaakur SR, Saraswathy GR, Maheswari E, Kumar NS, Hazarathiah T, Sowmya K, et al. Inhibition of $\mathrm{CCl} 4$ - induced liver fibrosis by Trigonella foenumgraecum Linn. Natural Product Radiance. 2007;6 (1):11-17.

2. Xie $W L$, Jiang $R$, Shen $X L$, Chen $Z Y$, Deng $X M$. Diosgenin attenuates hepatic stellate cell activation through transforming growth factor- $\beta / S m a d$ signaling pathway. Int J Clin Exp Med. 2015;8(11):2032320329.

3. Elpek GO. Cellular and molecular mechanisms in the pathogenesis of liver fibrosis: An update. World J Gastroenterol. 2014;20(23):7260-7276.

4. Henderson NC, Iredale JP. Liver fibrosis: cellular mechanisms of progression and resolution. Clinical Science. 2007:112:265-280.

5. Haga $Y$, Kanda T, Sasaki R, Nakamura M, Nakamoto $S$, Yokosuka O. Nonalcoholic fatty liver disease and hepatic cirrhosis: comparison with viral hepatitisassociated steatosis. World J Gastroenterol. 2015;21 (46):12989-12995.

6. Bert F. Liver Fibrosis: Difficulties in Diagnostic and Treatment: A Review. Gastro Med Res. 2017;1(1):18.

7. Weiskirchen R, Tacke F. Liver Fibrosis: Which Mechanisms Matter? Clinical Liver Disease. 2016;8(4):9499.

8. Lingwal P, Bhatt GK, Kothiyal P. Hepatic Stellate Cells as a Target for the Treatment of Liver Fibrosis. International Journal of Pharma Research \& Review. 2015;4(7):32-37.

9. Kolios G, Valatas V, Kouroumalis E. Role of Kupffer cells in the pathogenesis of liver disease. World $J$ Gastroenterol. 2006;12(46):7413-7420.

10. Chen SR, Chen XP, Lu JJ, Wang Y, Wang YT. Potent natural products and herbal medicines for treating liver fibrosis. Chinese Medicine.2015;10(7):1-13.

11. Yuan $Q$, Wu X, Huang W, Gong G, et al. Acute toxicity and sub-chronic toxicity of steroidal saponins 
Ravine et al. $\square$ Protective effect of Diosgenin against Carbon tetrachloride and Cisplatin induced hepatotoxicity in rats.

from Dioscorea zingiberensis C.H. Wright in rodents. Journal of Ethnopharmacology. 2009;126(3):543550.

12. Dong $S$, Chen $Q L$, Song $Y N$, Sun $Y$, Wei $B$, Li $X Y$, et al. mechanism of $\mathrm{CCl} 4$-induced liver fibrosis with combined transcriptomic and proteomic analysis. Journal of Toxicological Sciences. 2016;41(4);561-572.

13. Mir M, Arab MR, Shahraki MR. Toxic effects of cisplatin on hepatocytes and liver enzymes of rats. Anatomical Science. 2015;12(4):171-176.

14. Katagiri D, Hamasaki Y, Doi K, Negishi K, et al. Interstitial renal fibrosis due to multiple cisplatin treatments is ameliorated by semicarbazide-sensitive amine oxidase inhibition. Kidney International. 2016;89:374-385.

15. Rajesh MG, Latha MS. Protective activity of Glycyrrhiza glabra Linn. On carbon tetrachloride induced peroxidative damage. Indian J Pharmacol. 2004;36 (5):284-287.

16. Mustafa I, Elif O, Mukaddes G, Seda T. Protective effect of caffeic acid phenethyl ester (CAPE) administration on cisplatin-induced oxidative damage to liver in rat. Cell Biochem Funct. 2006;24:357-361.

How to Cite this article: Vikram V Nimbalkar, Ravina P Shelke, Urmila E Kadu, Dr. Pandurang M Gaikwad. Protective effect of Diosgenin against Carbon tetrachloride and Cisplatin induced hepatotoxicity in rats. Int. j. clin. biomed. res. 2018;4(3): 50-56. 